\title{
6
}

\section{Mediation of Political Realities: Media as Crucial Sources of Information}

\author{
Adam Shehata and Jesper Strömbäck
}

When we want to learn about the world around us, there are basically three perceptual sources of information: personal experiences, interpersonal communication and the media (Asp, 1986). We can learn things firsthand, by communicating with other people, or by taking part of different media.

For the most part, however, the media are the most important source of information. The reach of our own experiences is very limited, and the same holds true for most people we talk to. Particularly when it comes to politics and society, most of what we know - or think we know - we have learned from the media. Even in cases when we have some experiences on our own to base our knowledge on, without information from the media we do not know whether our experiences are representative of how things are or whether they are atypical (Mutz, 1998). For example, while we might have experiences of the local hospital, that does not tell us much about the quality of health care in general, and even less about factors influencing the health care system or what proposals there are to improve healthcare.

Consequently, it has become a truism that modern politics is largely mediated politics (Bennett \& Entman, 2000; Kaid et al., 1991; Nimmo \& Combs, 1983). The extent to which the media constitute the most important source of information about politics and society has also been labeled the first dimension of mediatization and singled out as a necessary prerequisite for further processes of mediatization (Strömbäck, 2008, 2011).

There might, however, be several reasons to revisit the notion that politics has become mediated and the evidence that the media are the most important source of information about politics and society. First and conceptually speaking, there is a need to distinguish between mediated and mediatized politics. Second, the media is a broad and heterogeneous category - including everything from books to newspapers, radio, television and increasingly digital media - and the relative importance of different media might vary across time as well as countries. Hence, there is a need 
to take a closer look at our current knowledge about what kind of media people rely on for information about politics and society. Third, new media technologies and social media have caused old boundaries to become blurred and opened up for virtual interpersonal communication, raising new questions about what "the media" refers to and the extent to which it is valid to use "the media" as a shorthand for traditional mass media such as television, newspapers and radio.

Against this backdrop, the purpose of this chapter is to briefly discuss the conceptual relationship between mediated and mediatized politics, to analyze research on the importance of different kinds of media as sources of information about politics and society, and to analyze the implications of the findings for the notion that "the media" is the most important source of information about politics and society and for mediatization theory.

\section{Mediation and mediatization: Conceptual similarities and differences}

While scholarly interest in processes of mediation and mediatization has increased during the last decade, oftentimes these concepts are used without clear conceptualizations, and it is also common that mediation and mediatization are used to denote the same phenomena. Although there are exceptions, particularly British and US scholars often appear to prefer the term "mediation" when analyzing how the media influence various spheres in society (Altheide \& Snow, 1988; Couldry, 2008; Davis, 2007; Livingstone, 2009; Nimmo \& Combs, 1983; Silverstone, 2007), while scholars from continental Europe and Scandinavia appear to favor the term "mediatization" (Asp, 1986; Kepplinger, 2002; Lundby, 2009; Mazzoleni \& Schulz, 1999; Hjarvard, 2013; Schillemans, 2012; Strömbäck, 2008). There might however be some development towards a convergence and an increasing consensus that "mediation" and "mediatization" refer to different processes (Hjarvard, 2013, p. 19).

From such a perspective and following Mazzoleni (2008a, 2008b), mediatization broadly refers to "the extension of the influence of the media (considered both as a cultural technology and as an organization)" in different spheres in society, whereas mediation refers to the rather neutral act of transmitting messages through different media (Strömbäck \& Esser, 2009; Strömbäck, 2011). In the context of politics, politics is thus mediated whenever political messages are transmitted or whenever people learn about politics through any kind of media, regardless of whether this process yields any influence or transforms the style or content of political communication. To say that something is mediated is simply to say that it is communicated through some kind of media - and it matters less conceptually whether the media in question are television, newspapers, radio, 
the Internet or smartphones. Thus, mediated politics stands in contrast to interpersonal communication or personal experiences.

Beyond this distinction between mediation and mediatization, there are however reasons to distinguish between mediation at different levels of analysis. At the micro level, politics is mediated whenever a political message is communicated or someone learns about politics through some kind of media. At this level of analysis, politics has to some extent been mediated as long as there has been some kind of media. Politics can also be more or less mediated. At the one extreme would be those who never learn about politics from any kind of media, whereas at the other extreme would be those who learn about politics only through different media.

The extent to which people learn about politics through different media has an effect on mediation at the macro level. At the macro level, politics is mediated when the media has become the most important source of information about politics and society and the primary channel of communication between political actors and citizens (Bennett \& Entman, 2001; Strömbäck, 2011). Mediated politics at the macro level can thus be understood as the aggregation of mediation of politics at the micro level.

The development of new media technologies has at the same time caused the concept of "the media" to become more heterogeneous and blurred. Most scholars analyzing the mediation and mediatization of politics usually apply "the media" as shorthand for traditional news media that function as institutions, i.e., television, newspapers and radio (Cook, 2005; Hjarvard, 2013; Strömbäck \& Esser, 2009). The rise of the Internet and other digital media, which mix content produced by institutional mass media and different political and advocacy organizations, as well as by ordinary citizens, has however made this practice less valid, while also blurring the line between mass communication and interpersonal communication and deinstitutionalizing the concept of "the media". Thus, not only is there a need to distinguish between mediated politics at the micro and the macro level, but also to separate mass-mediated politics from other kinds of mediation of political information and communication.

From the perspective of mediatization theory, the degree to which politics has become mediated constitutes an important part and necessary prerequisite for further processes of mediatization (Strömbäck, 2008, 2011; Mazzoleni, 2008a). What matters from that perspective is primarily the extent to which individuals rely on content produced and shaped by different news media as institutions (Esser, 2013; Hjarvard, 2013; Strömbäck, 2011), not whether they access the information through these media's traditional formats or their digital versions. It is thus less important whether people rely on the New York Times or nytimes.com for information about politics than if they rely on traditional news media institutions or on information coming directly, albeit through some kind of media, from, for example, political parties, governmental authorities or friends. 


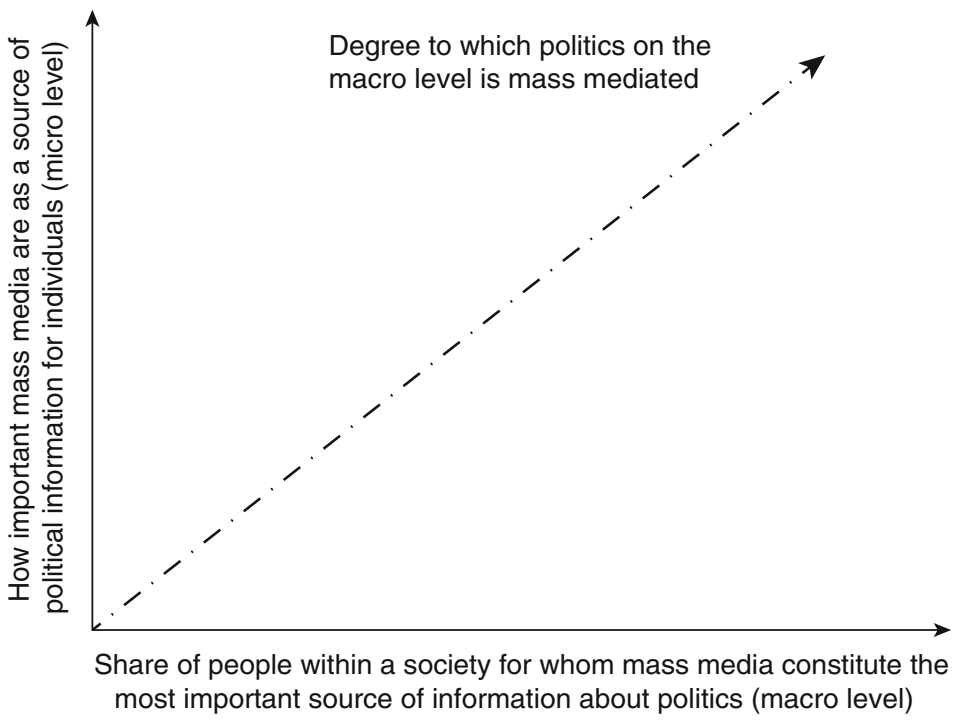

Figure 6.1 Mass-mediated politics at the micro and the macro level

The key question, then, is how important different mass media are as sources of political information for individuals and the share of people for whom the mass media constitute the most important source of information about politics and society. The more individuals rely on mass media for information about politics and society, and the larger the share of people for whom the mass media - in traditional or digital formats - constitute the most important source of information about politics and society, the more mass-mediated politics is (see Figure 6.1).

As the degree to which politics is mass-mediated theoretically influences further processes of mediatization, changes or differences across time or space in the degree to which politics is mass-mediated may have important implications for the mediatization of politics. Considering this and the changing media environments and patterns of media consumption, there is a need to take a closer look at the importance of media as sources of political information.

\section{Media as sources of information}

Because the notion that politics is mediated has become almost a truism, the claim that the media constitute the most important source of information is seldom critically examined. One additional reason may be that most media studies build on the idea that media is crucial for democracy, and research thus focuses not on whether but how and in what ways the media matter. 
Thus, the mediation of political information serves as a taken-for-granted assumption from which to push the research agenda forward. Another reason may be that there is no straightforward way of empirically assessing the importance of the media as an information source in societies where citizens are more or less embedded in a media environment from the day they are born. Furthermore, there are no agreed-upon benchmarks for distinguishing between information sources and evaluating their relative "importance" - an issue that becomes even more pressing as various forms of media use, interpersonal communication and political behavior mix and mingle as a result of media convergence.

Hence, investigating the importance of the media as a source of information about politics and society is not a simple task. In the research review that follows we will thus discuss three ways of analyzing the importance of traditional mass media compared to other sources of information about politics and current affairs: (1) asking people about their reliance on mediated communications for information about politics and current affairs; (2) analyzing the relationship between media coverage and awareness of political and current events; and (3) analyzing different sources of citizens' sociotropic perceptions of reality.

\section{Asking about citizens' reliance on mediated communications}

The most straightforward approach to investigating the importance of traditional mass media as a source of information about politics and society - i.e., the mediation of politics - is to ask people explicitly about their main sources of political information (Althaus, 2007; Eurobarometer, 2012; Gidengil, 2008; Norris \& Curtice, 2007; Pew, 2011). The literature contains various survey-based assessments of citizens' reliance on the media for information about politics and current affairs. Using respondents' self-reports of media reliance and use typically suggests a prominent role for mediated communication compared to personal experience and interpersonal communication as primary information sources.

For example, the Pew Research Center in the United States has for many years asked the following open-ended survey question: "How have you been getting most of your news about national and international issues? From television, from newspapers, from radio, from magazines, or from the Internet?" (Pew, 2008, 2011, 2013). Respondents are allowed to name two sources. As noted by Althaus and Tewksbury (2007), this approach has at least two advantages. First, it provides an estimate of respondents' selfreported relative importance of various media sources. Second, the question allows respondents to name other information sources than traditional news media, such as interpersonal discussions.

Evidence from both the United States and the 27 European member states, presented in Figure 6.2, suggests that television remains the dominant source 


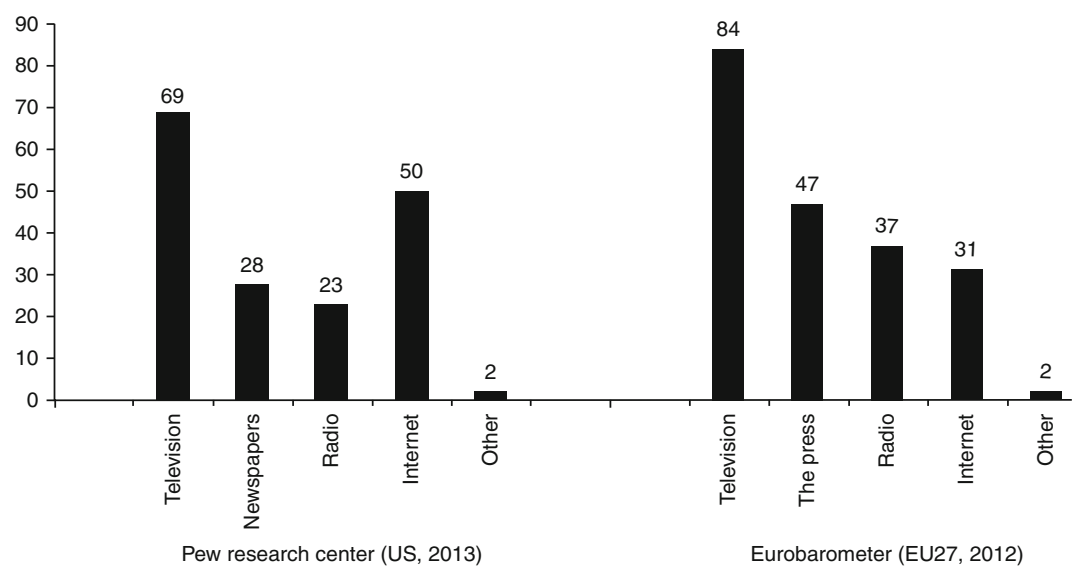

Figure 6.2 Most important source of news (\%)

Note: Data from the United States come from Pew Research Center (2013), who asked respondents' the following question in 2013: "How do you get most of your news about national and international issues?" Data from the European Union countries come from Eurobarometer (2012), who asked respondents' the following question in 2012: "Where do you get most of your news on national political matters?"

of political information - at least as assessed by citizens themselves. The European data is based on a Eurobarometer survey conducted in the 27 member states in 2012, where respondents were asked a question similar to the Pew question: "Where do you get most of your news on national political matters?" Apart from the fact that television comes out on top of the list in both surveys, some other observations from these studies are worth pointing out.

First, while the 2013 US data shows that television is the most important source of news about national and international issues, it is increasingly challenged by the Internet. While $69 \%$ named television as the most important source of information, the Internet was placed second (50\%), followed by newspapers $(28 \%)$, radio $(23 \%)$ and magazines $(4 \%)$. Television tends to dominate as a source of information for most Europeans (84\%) as well - it is perceived as the main source of information in all countries except for Luxemburg - but newspapers (47\%) and radio (37\%) are considered more important than the Internet (31\%).

Second, the relative importance of different sources of information varies between European Union member states. Newspapers are, for instance, more prominent in some countries than others, which may reflect historical, political and media system differences (Elvestad \& Blekesaune, 2008; Hallin \& Mancini, 2004; Shehata \& Strömbäck, 2011). Simply put, some countries are more television-centric while other countries are more newspaper-centric. 
Third, the number of respondents who named a source other than these media was extremely low in both surveys $(2 \%)$, which would indicate a negligible role for non-mediated forms of communication. It remains unclear from these data whether this is the case, though. Responses to open-ended questions like these may be highly sensitive to probing, i.e., whether interviewers explicitly mention specific news sources as examples when posing the questions (Schuman \& Presser, 1996). Furthermore, respondents may be cued to think about media more than other types of information sources when asked about their ways of getting "news". Therefore, it is not clear to what extent these measures provide valid estimates of the relative importance of media sources on the one hand, and personal experience and interpersonal communication on the other.

A slightly modified question was therefore posed to a representative sample of Swedish citizens during the 2006 national parliamentary election campaign (Strömbäck, 2009). Asked about their main source of information about the election campaign, respondents were provided with a list of not only traditional and new media, but interpersonal communication and personal contacts with politicians and parties as well. Still, very few respondents considered these unmediated sources as the most important. Television was placed as the number one source by $54 \%$ of the sample, followed by newspapers (25\%), Internet (8\%) and radio (6\%), while personal contacts with parties and politicians (4\%) and interpersonal communication with friends and family members (3\%) were the least important sources of campaign-related information.

Similar findings - based on similar survey items - indicating a prominent function of traditional media as sources of information during election campaigns have been documented in other countries as well, such as Britain and Canada (Gidengil, 2008; Norris \& Curtice, 2007; Scammell \& Semetko, 2008). Data from the 2005 British general election showed, for example, that traditional media such as television, newspapers and radio were by far the most commonly used sources of information (Norris \& Curtice, 2007). Approximately $50 \%$ of the respondents reported that they got information about the election campaign from these media. Almost the same share, 46\%, said they had discussed the election with friends or family members. By comparison, only $15 \%$ reported being contacted by a party or candidate, and even fewer (2\%) attended a public meeting about the election.

It is important to note, however, that getting political information primarily from television does not necessarily equal exposure to regular newscasts or special elections programs moderated by journalists, but also to more infotainment-oriented talk shows as well as political ads or party election broadcasts. Similarly, getting information primarily from the "Internet" says little about what websites citizens use, whether political party websites and blogs, social media or the online version of traditional news media. In essence, this suggests that it is misleading to think of getting information 
from the Internet as opposed to getting information from traditional news media. We will return to this question below.

While asking people about their primary source of political information is straightforward, this strategy comes with methodological problems. Most importantly, this approach rests on the assumption that respondents are able to reliably estimate their dependence on different types of media and interpersonal communication, and weigh their importance in relation to one another. An alternative way of assessing the role of the media as an information source is to analyze the relationship between media coverage and respondents' awareness of political and current events information.

\section{The relationship between media coverage and awareness of political and current events}

As an alternative approach to asking citizens about their sources of information about politics, several studies analyze the importance of the media by analyzing the influence of media coverage on citizens' awareness of current events and issues. Theoretically and following the OMA framework, variations in political knowledge among citizens are typically considered a function of learning opportunities, motivations and abilities (Delli Carpini \& Keeter, 1996; Luskin, 1990; Prior, 2007; Strömbäck et al., 2012). While motivations and abilities are individual-level factors expressing differences in personal interest and cognitive resources, the opportunities to learn are determined by the availability of political information in any given context (Aalberg et al., 2010; Esser et al., 2012). By using variations in the supply of media coverage of various topics, and thereby the opportunities for citizens to acquire this information, several studies have analyzed the influence of information provided by the media on citizens' awareness of current political issues and events (Curran et al., 2009; Delli Carpini et al., 1994; Jerit et al., 2006). The major lesson from this research is that citizens acquire a good deal of information about national and international political issues when this information is widely available in those media they have access to.

Several of the studies within this research area are particularly relevant in light of our interest in the media as a source of political information. While substantial scholarly attention has been devoted to the relationship between media use and political knowledge in general, the specific focus on awareness of current affairs news - what Delli Carpini and Keeter (1996) refer to as "surveillance facts" - is better suited for assessing the news media's role as an information source than more common measures of political knowledge. Compared to measures tapping knowledge of historical facts, institutions, rules of the game, party ideology and issue positions, acquiring surveillance knowledge "depends upon recent exposure to information in the media rather than learning that occurred years ago" (Jerit et al., 2006, p. 269). 
In a study of "passive learning", Zukin and Snyder (1984) compared citizens' awareness of candidates running for office in New Jersey and New York elections, based on geographical variations in the amount of media coverage devoted to the election campaigns. Despite equal interest in the election, residents living in media-rich markets with extensive coverage were $40 \%$ more likely to know about the candidates than citizens residing in media markets with substantially less election coverage (see also Delli Carpini et al., 1994).

While these results ascribe to the media a prominent role as information sources in election campaigns, the media markets of the late 1970s and early 1980s were very different from today's unconstrained high-choice media environments (Prior, 2007). Despite this, a number of recent studies have supported the idea that variations in information opportunities provided by major news media explain differences in awareness of current events and issues, beyond what is accounted for by individual-level characteristics. A number of cross-national comparative studies, using extensive media content analyses and survey data, have linked differences in the supply of hard and soft news to variations in citizens' awareness of domestic and international issues (Aalberg \& Curran, 2011; Curran et al., 2009; Iyengar et al., 2010; Iyengar et al., 2009). People living in media systems providing extensive hard news, and thereby greater opportunities for the average citizens to encounter political and current affairs information, were also more knowledgeable about those issues that were covered by the media. The availability of such information in the media was also related to smaller gaps in knowledge based on personal motivation and resources.

Evidence of the important role of media as disseminators of current events information in today's high-choice media environments does not only come from cross-national comparative research. A growing number of both crosssectional and longitudinal studies conducted in the United States as well as Europe show that the supply of political information in major news media increases knowledge and awareness of these issues among the electorate (Barabas \& Jerit, 2009; Elenbaas et al., 2012, 2013; Jerit et al., 2006; Nadeau et al., 2008). For instance, Barabas and Jerit (2009) used a large number of surveys conducted in the United States to analyze how policyspecific knowledge on a range of issues - such as gun control, health care and social security - was influenced by media coverage of these topics. Among other things, they found not only that increases in the amount of coverage devoted to an issue were related to higher levels of policy-specific knowledge, but also that the breadth and prominence of these news stories increased the opportunities to acquire this information. Using a very similar research design but in a European context, Elenbaas et al. $(2012,2013)$ showed "that a wider distribution of political information in the media strongly increases the odds that citizens acquire that information" (Elenbaas et al., 2012, p. 15). 
These studies clearly suggest that media matter and that politics is mediated: awareness and knowledge of political current affairs varies according to the availability and prominence of this information in major news media outlets. What is less clear, however, is whether this information mainly spreads to citizens directly from media exposure, or through various indirect communication flows. To be sure, there are studies indicating that some of the variation in current events knowledge can be attributed to citizens' personal media exposure diets, and that both passive and motivated learning occur from the media (Elenbaas et al., 2013; Shehata, 2013; Soroka et al., 2012), but several obstacles inhibit firm conclusions regarding the relative importance of various sources of information at the individual level. To begin with, despite the fact that many studies have investigated the relationship between news media use and political knowledge, there are - apart from the research discussed above - few that focus on awareness of current news events or surveillance knowledge. In addition, survey measures of individual-level news consumption are plagued with methodological problems such as overreporting, which limits their use as reliable indicators of actual news exposure (Price \& Zaller, 1993; Prior, 2009). Finally, analyzing the relationship between individual-level news exposure and knowledge of current events becomes problematic in situations of information saturation, i.e., when the information is widely available across media outlets and in public deliberation - which tends to be the case with major breaking news that dominate the agenda (Druckman, 2005; Elenbaas et al., 2012; Zukin \& Snyder, 1984). In those cases it becomes almost impossible to distinguish the influence of media coverage from other sources of information such as interpersonal communication. This can be perceived as an example of amalgamation, which Schulz (2004) suggested is one effect of mediatization.

While the research discussed above undoubtedly suggests that the media play a significant role as providers of political and current affairs information, these studies say little about the relative importance of mediated communication compared to interpersonal discussions and personal experience. This question has, however, been at the heart of research on the formation of sociotropic perceptions.

\section{Mediated communication in the formation of sociotropic perceptions}

The relative influence of media coverage, interpersonal communication and personal experience on citizens' sociotropic perceptions has been a key issue in research on voting and agenda-setting. The sources of citizens' perceptions of collective experience became a critical question as research on economic voting consistently showed that judgments of national economic (sociotropic) trends were more important than personal pocketbook issues for explaining electoral behavior (Kinder, 1981; Lewis-Beck \& Stegmaier, 
2007). Similarly, the sources of sociotropic perceptions have been at the center of research on agenda-setting theory, according to which the traditional news media are hypothesized to exert a strong influence on what issues the public consider important national problems (McCombs, 2004).

Both these research traditions ascribe to the media a central role in forming citizens' sociotropic perceptions, i.e., perceptions of societal or national-level conditions. Media influence is not considered unconditional, however. Rather, most of this research builds on some version of media system dependency (MSD) theory (Ball-Rokeach, 1985). MSD is founded on the idea that power relations originate from control over resources that other actors need in order to fulfill their goals. The more exclusive these resources are, and the more other actors require these resources, the more asymmetric the power relation. According to MSD, media power is based on controlling access to information that media consumers require in order to achieve their particular goals, whatever these goals are:

The process of media effects is initiated by media control over scarce and prized information sources - gathering, processing, and dissemination - that must be accessed in order for the larger social system, as well as members of the media audiences, to achieve a range of goals [...] The more exclusive the media system's control over these resources, and the more essential it is to have access to these resources to achieve goals, the more likely it is that there will be media effects.

(Ball-Rokeach \& Jung, 2009, p. 533)

Exclusivity is crucial in this regard. Citizens who have access to other sources of information on a given topic are consequently less dependent on the media when forming perceptions and opinions. Research on the formation of sociotropic perceptions has primarily addressed the competing or complementary influences of personal experience and interpersonal communication as alternative sources of information. While some of this research has treated personal experience and interpersonal communication as competing factors, others emphasize the interactive and reciprocal relations between different sources of information as citizens form perceptions of collective experience. The basic question, though, concerns the conditions under which citizens use information from the mass media, personal experience and interpersonal communication when making inferences about collective experience.

Agenda-setting research focusing on the contingencies of media influence on sociotropic perceptions has - based on MSD - analyzed the role of issue obtrusiveness, i.e., citizens' direct personal experience of various topics, as a moderating factor (Demers et al., 1989; Watt et al., 1993). Several of these studies support the basic premise of MSD theory: the agenda-setting influence of the mass media is stronger for issues that people have little direct 
experience with. Limited personal experience means less information from non-mediated sources, and media dependency becomes stronger. Soroka (2002) found, for instance, that agenda-setting effects on public opinion were stronger for unobtrusive issues such as environmental problems and government debt and deficits than for the obtrusive inflation issue. While unobtrusiveness seems to enhance the role of mediated communication, the findings are somewhat mixed for obtrusive issues. Some studies suggest that personal experiences constrain the agenda-setting impact of the media, while others find that media coverage influences citizens' sociotropic perceptions of obtrusive issues as well (Demers et al., 1989; Goss \& Aday, 2003; Hügel et al., 1989; Iyengar \& Kinder, 1987; Watt et al., 1993).

Even though there is mixed evidence regarding whether issue obtrusiveness reduces the media's agenda-setting influence, there is less disagreement that both personal experience and interpersonal communication exert independent effects on perceived issue importance at the societal level (Iyengar \& Kinder, 1987; Wanta \& Hu, 1990). People experiencing unemployment are, for example, more likely to consider this an important issue, just as talking to friends and family about crime influences sociotropic perceptions.

The most convincing account of how media coverage, personal experience and discussions influence sociotropic perceptions emphasizes the mutual and interactive - rather than competing - effects of these factors. Such a perspective may explain (1) some of the inconsistent findings regarding the role of personal experience as a moderator of agenda-setting effects, as well as (2) the relatively weak findings for agenda-setting effects at the individual level (Erbring et al., 1980; Roessler, 2008). Whenever citizens can rely on personal experience or interpersonal discussion networks, mediated communication may be an integral factor in the formation of sociotropic perceptions, but rarely in an unfiltered way. Alternative information sources can both reduce or enhance media influence on perceptions of collective experience. Conversely, the impact of personal experience on perceptions of collective experience may be dependent on mediated communications.

In one of the most extensive analyses of the influence of personal experiences and mediated communication on sociotropic perceptions, Mutz (1998) found that the mass media have a dual role in politicizing personal experience. Focusing on unemployment, she found that the mass media were the primary influence on perceptions of national trends while personal experience was the main source of personal-level judgments (see also Goss \& Aday, 2003). In the absence of mediated information, however, sociotropic perceptions depended more on personal experiences:

[i]ndividual-level variations in perceptions of unemployment conditions are, in fact, meaningful; they primarily demonstrate differences in the amount and type of information available to people. Those with much 
information from mass media sources will have perceptions of unemployment consistent with media presentations, while those relying on more parochial sources will have perceptions that reflect their immediate environments.

(Mutz, 1992, p. 502)

With respect to the interaction between mediated communication and personal experience, Mutz (1994) also found that heavy media coverage of unemployment increasingly colored national-level unemployment perceptions. Thus, extensive media coverage helps citizens to connect the personal with the political by "exposing people to the similar experiences of others" (Mutz, 1994, p. 692).

The importance of the media as a source of information about politics and society (sociotropic perceptions) at the individual level depends, therefore, on other factors. Research on the contingent conditions of media influence suggests that mediated information flows are more likely to be adopted if these messages are consonant with citizens' perceptions of their personal experiences as well as the content of their interpersonal discussions (Chong \& Druckman, 2007; Demers et al., 1989; Mutz, 1998). Several agenda-setting studies have also supported the "issue sensitivity" hypothesis, indicating that sociotropic perceptions are shaped by an interactive influence of media coverage and audience characteristics (Erbring et al., 1980; Iyengar \& Kinder, 1987; Roessler, 1999). Based on their experimental studies of media effects, Iyengar and Kinder concluded, for instance, that "when problems flare up and capture the attention of the media, agendasetting effects show up most immediately among those directly affected by the problem" (1987, pp. 52-53). Similarly, another individual-level agendasetting analysis found weak direct effects of media coverage on perceived issue importance, concluding that "[p]ieces of information are retrieved from many other sources and permanently modified by discussions with other people or individual processing of the respondent" (Roessler, 1999, p. 691). In a similar vein, several agenda-setting studies suggest that individual variations in citizens' need for orientation with respect to certain issues influence the tendency to seek out information from the media (McCombs, 2004).

In sum, while it remains difficult to assess the relative importance of various sources of information on sociotropic perceptions, research suggests that mediated communication, personal experience and interpersonal discussions are best conceived of as interactive factors in the formation of sociotropic perceptions. Based on the discussion above, it thus seems reasonable to conclude that (1) personal experiences and interpersonal discussions do shape perceptions of collective experience, and even more so in the absence of media coverage; (2) mediated information flows can both weaken and strengthen the relationship between personal experiences and 
sociotropic perceptions; (3) media coverage has the strongest influence on sociotropic perceptions of unobtrusive issues; and (4) the impact of mediated communication on sociotropic perceptions is dependent on whether media messages are in line or at odds with personal experiences and interpersonal discussions.

\section{The mediation of politics in high-choice media environments}

Learning about politics and society is obviously a function of various contextual and individual-level factors. As noted previously, the OMA framework provides a general overview of how information opportunities as well as personal motivations and abilities influence learning about politics and society (Delli Carpini \& Keeter, 1996; Luskin, 1990). While mediated communication is likely to be crucial as a source of political information, the specific importance of various media is thus dependent not only on differences in interests, preferences and resources among citizens, but also on the larger social, technological and cultural transformations that have occurred during the last few decades (Bennett \& Iyengar, 2008; Prior, 2007; Stroud, 2011).

In particular, the profound media environmental changes - with a multiplication of output across platforms, channels and outlets - have substantially altered the opportunities for citizens to encounter political information as part of their everyday lives. Not only has the number of media sources from which people can learn grown, but so has the complexity and variation in how citizens can acquire such information through a combination of mediated offline and online sources. As argued by Bennett and Manheim (2006, p. 22), information consumption has shifted away from mass to individualized experience, which becomes evident as one compares "the appointment-based society that gathered around network broadcast news with the emergence of the podcast society increasingly driven by personalized, on-demand news aggregators" (see also Chaffee \& Metzger, 2001). While the societal and individual-level consequences of these media environmental changes in terms of media use, political involvement and opinion formation have yet to be thoroughly analyzed as the process unfolds, the implications for the mediation of politics may become substantial.

Using MSD theory (Ball-Rokeach \& Jung, 2009) as a point of departure, the transformation from low-choice to high-choice media environments most obviously seems to liberate individuals from their dependency on traditional news media for information about politics and society. If dependency is based on controlling others' access to scarce resources, the proliferation of alternative sources of political information undermines the unique role of traditional mass media as possessors and disseminators of exclusive information. What is theoretically possible, however, may not necessarily equal actual changes and practices. 
To be sure, the trend of shrinking audiences for news media on traditional platforms seems to be consistent across Western democracies (Blekesaune et al., 2012; Prior, 2007; Strömbäck et al., 2012). However, this does not mean that citizens are necessarily becoming less dependent on media per se, or that they actively seek information about politics from the full range of alternative sources now available to them. While a recent study found that citizens who rely on multiple online news sources were less inclined to base their sociotropic perceptions on cues from the traditional news media (Shehata \& Strömbäck, 2013), evidence strongly suggests that citizens who get their news about politics from the Internet mainly turn to the websites of the traditional media. Among Europeans who use the Internet as a source of information about national politics, almost 70\% said they got their news from information websites such as newspapers and news magazines, followed by social network sites (27\%), government websites (24\%), blogs (11\%) and video hosting websites (8\%) (Eurobarometer, 2012). Based on a similar pattern in the United States, Mutz and Young (2011, pp. 1027-1029) concluded that "even in the realm of new media, traditional media sources dominate. And, while an increasing number of people get their news online, few online newspaper sites look much different from their paper-and-ink predecessors and most present the same news to their online and offline readers."

Thus, it would be a mistake to equate the rising importance of the Internet as a source of information about politics and society with a declining importance of traditional news media. As long as people when using the Internet as a source of information mainly turn to the digital versions of traditional mass media, the Internet does not substitute traditional mass media, and politics does not become less mediated.

The most important consequence of digital media in the realm of information flows and mediation is thus probably not the substitution of traditional mass media. What is likely to become more important is rather (1) the increasing mixing and mingling of information coming from traditional mass media and advocacy organizations, businesses and other non-media organizations, as well as through traditional or virtual interpersonal communication; (2) the increasing fragmentation and individualization of media and information consumption patterns; and (3) the continuous formation of multiple-step flows of information, where information originating with traditional mass media flow - and in the process mix and mingle with other information - through social networks of communication online and offline before reaching the individual consumers of information. There will be less inadvertent exposure to traditional news media in their traditional formats and more to different types of mediated multiple-step flows of information in the future than in the past, but this does not in itself make traditional news media as an institution less important or politics less mediated. 


\section{Discussion and conclusions}

It has long been a truism that modern politics largely is mediated politics, i.e., politics mainly communicated through different mass media with the mass media being the most important source of information about politics and society. The (mass) mediation of politics is also an important prerequisite for the mediatization of politics, so changes in this respect would potentially have significant implications for the mediatization of politics.

The mediation of politics is however not a question of either/or. It is rather a matter of degree, and to fully understand the extent to which politics is mediated, there is reason to distinguish between mediation at the micro and the macro level. At the micro level, the key question is how important mass media are as a source of information about politics and society for individuals, while at the macro level the key question is the share of people within a society for whom the mass media are the most important source of information about politics and society. The more individuals rely on mass media for information about politics and society, and the larger the share of people for whom mass media - in traditional or digital formats - constitute the most important source of information about politics and society, the more mediated politics is (see Figure 6.1).

Despite the taken-for-granted assumption that modern politics is largely mediated politics, our review shows that it is not easy to determine the extent to which individuals rely on mass media for information about politics and society, and hence the degree to which politics at the micro and the macro levels is mediated. While all evidence suggests that mass media are extremely important as a source of information about politics and society, and that politics is indeed mediated, there is no obvious approach in examining exactly how important the media are as a source of political information. Different approaches yield somewhat different, albeit not contradictory results, and the degree of media dependency might vary across not only individuals within or between countries, but also depending on the nature of different issues and the availability of alternative sources of information.

Thus, if one conclusion is that politics is still highly mediated, another conclusion is that it is difficult to determine the degree to which politics at the micro or the macro level is mediated. One implication is hence that there is a need for further research on the relative importance of different sources of information about politics and society, and that the mediation of politics should not just be treated as a truism.

Still, if it is difficult to assess the extent to which people rely on mass media for information about politics and society today, it will become even more difficult in the future as media environments continue to change, different media continue to converge, different sources of information continue to mix and mingle, and different multiple-step flows of information 
through various social networks continue to develop and blur the distinction between types of information as well as the origins of information.

Considering the focus in contemporary research and public discourse on the increasing importance of the Internet, it is however important not to focus too much on the technical platforms through which information flows. What matters most from the perspective of the mediation and mediatization of politics is not primarily the technical platforms through which people get information about and experience politics and society. What matters most is how important the mass media as an institution is as a source of information about politics and society. More important than how many use the Internet to learn about politics and society is thus how people use the Internet and the extent to which they turn to mass media in their traditional or digital versions to find information about politics and society.

Thus, the rising importance of the Internet does not necessarily herald the demise of mediated politics, nor of the mediatization of politics. It might rather herald the re-mediation of politics. This might have implications for the mediatization of politics in the future, but as long as the mass media in their traditional or digital formats - continue to be the most important source of information about politics and society, while being largely autonomous from political institutions, politics will continue to be both mediated and mediatized.

\section{References}

Aalberg, T., \& Curran, J. (Eds.) (2011). How Media Inform Democracy: A Comparative Approach. London: Routledge.

Aalberg, T., van Aelst, P., \& Curran, J. (2010). Media Systems and the Political Information Environment: A Cross-National Comparison. International Journal of Politics, 15(3), 255-271.

Althaus, S. (2007). Free Falls, High Dives, and the Future of Democratic Accountability. In D. Graber, D. McQuail \& P. Norris (Eds.), The Politics of News - The News of Politics. Washington, DC: CQ Press.

Althaus, S., \& Tewksbury, D. (2007). Toward a New Generation of Media Use Measures. Pilot study report presented to the Board of Overseers of the American National Election Studies.

Altheide, D. L., \& Snow, R. P. (1988). Toward a Theory of Mediation. In J. A. Anderson (Ed.), Communication Yearbook 11 (pp. 194-223). Newbury Park: Sage.

Asp, K. (1986). Mäktiga massmedier: Studier i politisk opinionsbildning. Stockholm: Akademilitteratur.

Ball-Rokeach, S. (1985). The Origins of Individual Media-system Dependency Theory: A Sociological Framework. Communication Research, 12(4), 485-510.

Ball-Rokeach, S., \& Jung, J. (2009). The Evolution of Media System Dependency Theory. In R. Nabi \& M. B. Oliver (Eds.), The Sage Handbook of Media Processes and Effects. Thousand Oaks: Sage.

Barabas, J., \& Jerit, J. (2009). Estimating the Causal Effects of Media Coverage on Policy-Specific Knowledge. American Journal of Political Science, 53(1), 73-89. 
Bennett, W. L., \& Entman, R. M. (Eds.) (2001). Mediated Politics: Communication and the Future of Democracy. New York, NY: Cambridge University Press.

Bennett, L., \& Iyengar, S. (2008). A New Era of Minimal Effects? The Changing Foundations of Political Communication. Journal of Communication, 58(4), 707-731.

Bennett, L., \& Manheim, J. (2006). The One-Step Flow of Communication. The ANNALS of the American Academy of Political and Social Science, 608(1), 213-232.

Bennett, W. L., \& Entman, R. M. (Eds.) (2001). Mediated Politics: Communication in the Future of Democracy. New York, NY: Cambridge University Press.

Blekesaune, A., Elvestad, E., \& Aalberg, T. (2011). Tuning Out the World of News and Current Affairs. An Empirical Study of Europe's Disconnected Citizens. European Sociological Review, 27(6), 110-126.

Chaffee, S., \& Metzger, M. (2001). The End of Mass Communication? Mass Communication \& Society, 4(4), 365-379.

Chong, D., \& Druckman, J. (2007). A Theory of Framing and Opinion Formation in Competitive Elite Environments. Journal of Communication, 57(1), 99-118.

Cook, T. E. (2005). Governing with the News: The News Media as a Political Institution. 2nd Edition. Chicago, IL: University of Chicago Press.

Couldry, N. (2008). Mediatization or Mediation? Alternative Understandings of the Emergent Space of Digital Storytelling. New Media \& Society, 10(3), 373-391.

Curran, J., Iyengar, S., Lund, A. B., \& Salovaara-Moring, I. (2009). Media System, Public Knowledge \& Democracy: A Comparative Study. European Journal of Communication, 24(1), 5-26.

Davis, A. (2007). The Mediation of Power: A Critical Introduction. London: Routledge.

Delli Carpini, M., Keeter, S., \& Kennamer, D. (1994). Effects of the News Media Environment on Citizen Knowledge of State Politics and Government. Journalism Quarterly, 71(2), 443-456.

Delli Carpini, M. X., \& Keeter, S. (1996). What Americans Know about Politics and Why It Matters. New Haven, CT: Yale University Press.

Demers, D., Craff, D., Choi, Y., \& Pessin, B. (1989). Issue Obtrusiveness and the Agenda-Setting Effects of National Network News. Communication Research, 16(6), 793-812.

Druckman, J. (2005). Media Matter: How Newspapers and Television News Cover Campaigns and Influence Voters. Political Communication, 22(4), 463-481.

Elenbaas, M., Boomgaarden, H., Schuck, A., \& De Vreese, C. (2013). The Impact of Media Coverage and Motivation on Performance-Relevant Information. Political Communication, 30(1), 1-16.

Elenbaas, M., De Vreese, C., Schuck, A., \& Boomgaarden, H. (2012, 2013). Reconciling Passive and Motivated Learning: The Saturation-Conditional Impact of Media Coverage and Motivation on Political Information. Communication Research, first online 20 November 2012, DOI 0093650212467032.

Elvestad, E., \& Blekesaune, A. (2008). Newspaper Readers in Europe: A Multilevel Study of Individual and National Differences. European Journal of Communication, 23(4), $425-447$.

Erbring, L., Goldenberg, E., \& Miller, A. (1980). Front-Page News and Real-World Cues: A New Look at Agenda-Setting by the Media. American Journal of Political Science, 24(1), 16-49.

Esser, F. (2013). Mediatization as a Challenge: Media Logic Versus Political Logic. In H. Kriesi, S. Lavenex, F. Esser, J. Matthes, M. Bühlmann \& D. Bochsler (Eds.), Democracy in the Age of Globalization and Mediatization (pp. 155-176). Basingstoke: Palgrave Macmillan. 
Esser, F., de Vreese, C. H., Strömbäck, J., van Aelst, P., Aalberg, T., Stanyer, J., Lengauer, G., Berganza, R., Legnante, G., Papathanassopoulos, S., Salgado, S., Sheafer, T., \& Reinemann, C. (2012). Political Information Opportunities in Europé: A Longitudinal and Comparative Study of Thirteen Television Systems. International Journal of Press/Politics, 17(3), 247-274.

Eurobarometer (2012). Media Use in the European Union, Standard Eurobarometer 78. Survey carried out by TNS Opinion \& Social at the request of the European Commission, Directorate-General Communication. Available at http://ec.europa.eu/public _opinion/archives/eb/eb78/eb78_media_en.pdf

Gidengil, E. (2008). Media Matter: Election News in Canada. In J. Strömbäck \& L. Lee Kaid (Eds.), The Handbook of Election News Coverage around the World. New York, NY: Routledge.

Goss, K., \& Aday, S. (2003). The Scary World in your Living Room and Neighborhood: Using Local Broadcast News, Neighborhood Crime Rates, and Personal Experience to Test Agenda Setting and Cultivation. Journal of Communication, 53(3), 411-426.

Hallin, D. C., \& Mancini, P. (2004). Comparing Media Systems: Three Models of Media and Politics. New York, NY: Cambridge University Press.

Hjarvard, S. (2013). The Mediatization of Culture and Society. London: Routledge.

Hügel, R., Degenhardt, W., \& Weiss, H. (1989). Structural Equation Models for the Analysis of the Agenda-setting Process. European Journal of Communicaiton, 4(2), 191-210.

Iyengar, S., Curran, J., Brink Lund, A., Salovaara-Moring, I., Hahn, K. S., \& Coen, S. (2010). Cross-National Versus Individual-Level Differences in Political Information: A Media Systems Perspective. Journal of Elections, Public Opinion \& Parties, 20(3), 291-309.

Iyengar, S., Hahn, K., Bonfadelli, H., \& Marr, M. (2009). "Dark Areas of Ignorance" Revisited. Communication Research, 36(3), 341-358.

Iyengar, S., \& Kinder, D. R. (1987). News That Matters. Chicago, IL: University of Chicago Press.

Jerit, J., Barabas, J., \& Bolsen, T. (2006). Citizens, Knowledge and the Information Environment. American Journal of Political Science, 50(2), 266-282.

Kaid, L. L., Gerstlé, J., \& Sanders, K. R. (Eds.) (1991). Mediated Politics in Two Cultures: Presidential Campaigning in the United States and France. Westport: Praeger.

Kepplinger, H. M. (2002). Mediatization of Politics: Theory and Data. Journal of Communication, 52(4), 972-986.

Kinder, D. (1981). Presidents, Prosperity, and Public Opinion. Public Opinion Quarterly, 45(1), 1-21.

Lewis-Beck, M. S., \& Stegmaier, M. (2007). "Economic models of voting." In R. Dalton \& H.-D. Klingemann (Eds.), The Oxford Handbook of Political Behavior. Oxford: Oxford University Press.

Livingstone, S. (2009). On the Mediation of Everything. Journal of Communication, 59(1), 1-18.

Lundby, K. (2009). Introduction: 'Mediatization' as Key. In K. Lundby (Ed.), Mediatization. Concept, Changes, Consequences (pp. 1-18). New York, NY: Peter Lang.

Luskin, R. (1990). Explaining Political Sophistication. Political Behavior, 12(4), 331-361.

Mazzoleni, G. (2008a). Mediatization of Politics. In W. Donsbach (Ed.), The International Encyclopedia of Communication (Vol. VII, pp. 3047-3051). Malden, MA: Blackwell. 
Mazzoleni, G. (2008b). Mediatization of Society. In W. Donsbach (Ed.), The International Encyclopedia of Communication (Vol. VII, pp. 3052-3055). Malden, MA: Blackwell.

Mazzoleni, G., \& Schulz, W. (1999). Mediatization of Politics: A Challenge for Democracy? Political Communication, 16(3), 247-261.

McCombs, M. (2004). Setting the Agenda: The Mass Media and Public Opinion. Cambridge, MA: Polity Press.

Mutz, D. (1992). Mass Media and the Depoliticization of Personal Experience. American Political Science Review, 36(2), 483-508.

Mutz, D. (1994). Contextualizing Personal Experience: The Role of the Mass Media. The Journal of Politics, 56(3), 689-714.

Mutz, D. (1998). Impersonal Influence: How Perceptions of Mass Collectives Affect Political Attitudes. Cambridge, MA: Cambridge University Press.

Mutz, D., \& Young, L. (2011). Communication and Public Opinion: Plus Ça Change? Public Opinion Quarterly, 75(5), 1018-1044.

Nadeau, R., Nevitte, N., Gidengil, E., \& Blais, A. (2008). Election Campaigns as Information Campaigns: Who Learns What and Does It Matter? Political Communication, 25(3), 229-248.

Nimmo, D., \& Combs, J. E. (1983). Mediated Political Realities. New York, NY: Longman.

Norris, P., \& Curtice, J. (2007). Getting the Message Out: A Two-Step Model of the Role of the Internet in Campaign Communication Flows during the 2005 British General Election. Journal of Information Technology \& Politics, 4(4), 3-13.

Pew Research Center. (2008). Internet Overtakes Newspapers as News Outlet. Washington, DC: Pew Research Center.

Pew Research Center. (2011). Internet Gains on Television as Public's Main News Source. More Young People Cite Internet than TV. Washington, DC: Pew Research Center.

Pew Research Center. (2013). Amid Criticism, Support for Media's "Watchdog" Role Stands Out. Washington, DC: Pew Research Center.

Price, V., \& Zaller, J. (1993). Who Gets the News? Alternative Measures of News Reception and Their Implications for Research. Public Opinion Quarterly, 57, 133-164.

Prior, M. (2007). Post-Broadcast Democracy: How Media Choice Increases Inequality in Political Involvement and Polarizes Elections. New York, NY: Cambridge University Press.

Prior, M. (2009). The Immensely Inflated News Audience: Assessing Bias in Selfreported News Exposure. Public Opinion Quarterly, 73(1), 130-143.

Roessler, P. (1999). The Individual Agenda-Designing Process: How Interpersonal Communication, Egocentric Networks, and Mass Media Shape the Perception of Political Issues by Individuals. Communication Research, 26(6), 666-700.

Roessler, P. (2008). Agenda-Setting, Framing and Priming. In W. Donsbach \& M. Traugott (Eds.), The Sage Handbook of Public Opinion Research. London: Sage.

Scammell, M., \& Semetko, H. (2008). Election News Coverage in the U.K. In J. Strömbäck \& L. Lee Kaid (Eds.), The Handbook of Election News Coverage around the World. New York, NY: Routledge.

Schillemans, T. (2012). Mediatization of Public Services: How Organizations Adapt to News Media. Frankfurt am Main: Peter Lang.

Schulz, W. (2004). Reconstructing Mediatization as an Analytical Concept. European Journal of Communication, 19(1), 87-101.

Schuman, H., \& Presser, S. (1996). Questions and Answers in Attitude Surveys: Experiments on Question Form, Wording, and Context. Thousand Oaks: Sage. 
Shehata, A. (2013). Active or Passive Learning from Television? Political Information Opportunities and Knowledge Gaps during Election Campaigns. Journal of Elections, Public Opinion \& Parties, 23(2), 200-222.

Shehata, A., \& Strömbäck, J. (2011). A Matter of Context: A Comparative Study of Media Environments and News Consumption Gaps in Europe. Political Communication, 28(1), 110-134.

Shehata, A., \& Strömbäck, J. (2013). Not (Yet) a New Era of Minimal Effects: A Study of Agenda Setting at the Aggregate and Individual Levels. International Journal of Press/Politics, 18(2), 234-255.

Silverstone, R. (2007). Media and Morality: On the Rise of the Mediapolis. Cambridge, MA: Polity.

Soroka, S. (2002). Issue Attributes and Agenda-Setting by the Media, the Public, and Policymakers in Canada. International Journal of Public Opinion Research, 14(3), 264-285.

Soroka, S., Andrew, B., Aalberg, T., Iyengar, S., Curran, J., Coen, S., Hayashi, K., Jones, P., Mazzoleni, G., Rhee, J., Rowe, D., \& Tiffen, R. (2012). Auntie knows Best? Public Broadcasters and Current Affairs Knowledge. British Journal of Political Science, 43(4), 719-739.

Strömbäck, J. (2008). Four Phases of Mediatization: An Analysis of the Mediatization of Politics. The International Journal of Press/Politics, 13(3), 228-246.

Strömbäck, J. (2009). Att studera valrörelser. In L. Nord \& J. Strömbäck (Eds.), Väljarna, partierna och medierna: En studie av politisk kommunikation i valrörelsen 2006 (pp. 9-28). Stockholm: SNS Förlag.

Strömbäck, J. (2011). Mediatization of Politics: Toward a Conceptual Framework for Comparative Research. In E. P. Bucy \& R. L. Holber (Eds.), Sourcebook for Political Communication Research. Methods, Measures, and Analytical Techniques. New York, NY: Routledge.

Strömbäck, J., Djerf-Pierre, M., \& Shehata, A. (2012). The Dynamics of Political Interest and News Media Consumption: A Longitudinal Perspective. International Journal of Public Opinion Research, 25(4), 414-435.

Strömbäck, J., \& Esser, F. (2009). Shaping Politics: Mediatization and Media Interventionism. In K. Lundby (Ed.), Mediatization. Concept, Changes, Consequences (pp. 205-224). New York, NY: Peter Lang.

Stroud, N. J. (2011). Niche News: The Politics of News Choice. New York, NY: Oxford University Press.

Wanta, W., \& Hu, Y. (1990). Interpersonal Communication and the Agenda-Setting Process. Journalism \& Mass Communication Quarterly, 69(4), 847-855.

Watt, J., Mazza, M., \& Snyder, L. (1993). Agenda-Setting Effects of Television News Coverage and the Effects Decay Curve. Communication Research, 20(3), 408-435.

Zukin, C., \& Snyder, R. (1984). Passive Learning: When the Media Environment Is the Message. Public Opinion Quarterly, 48(3), 629-638. 